PRETHODNO PRIOPĆENJE

UDK: 336.763 .2

Ines Megla, mag. oec.*

Izv. prof. dr. sc. Nataša Kurnoga **

Doc. dr. sc. Denis Dolinar ***

\title{
PRIMJENA VALUE-AT-RISK METODE U ANALIZI SASTAVNICA INDEKSA CROBEX10
}

\author{
THE VALUE-AT-RISK ANALYSIS \\ OF THE CROBEX10 INDEX CONSTITUENTS
}

\begin{abstract}
SAŽETAK: Rad se bavi karakteristikama VaR (Value-at-Risk) metoda na hrvatskome tržištu kapitala. Poseban naglasak rada je stavljen na procjenu VaR pokazatelja u kontekstu sučeljavanja efikasnosti indeksa CROBEX10 s odabranim portfolijima njegovih sastavnica s efikasne granice: portfolijem s maksimalnim odnosom prinosa i rizika (MPR) i portfolijem s minimalnom varijancom (MV). Istraživanje potvrđuje dosadašnje spoznaje da je povijesna VaR metoda pogodnija za hrvatsko tržište kapitala u odnosu na VaR metodu varijanci-kovarijanci. Utvrđeno je da kod MPR i MV portfolija VaR metoda varijanci-kovarijanci iskazuje veći stupanj rizika u odnosu na povijesnu VaR metodu. S druge strane, kod indeksa CROBEX10 VaR metoda varijanci-kovarijanci iskazuje manji stupanj rizika u odnosu na povijesnu VaR metodu. Portfoliji MPR i MV u većini slučajeva imaju manji stupanj rizika u odnosu na indeks CROBEX10. Konačno, portfoliji MPR i MV koji su testirani izvan uzorka iskazuju veći stupanj rizika u odnosu na portfolije MPR i MV koji su testirani unutar uzorka.
\end{abstract}

KLJUČNE RIJEČI: rizična vrijednost, VaR, tržišni rizik, CROBEX10, efikasna granica.

SUMMARY: This paper explores characteristics of the VaR (Value-at-Risk) methods for the Croatian capital market. A special focus is taken when estimating the VaR in a context of comparing an efficiency of the CROBEX10 index with selected portfolios of the CROBEX10 constituents from an efficient frontier: the maximum return/risk ratio (MRR) portfolio and the minimum variance (MV) portfolio. Research confirms that the historical VaR method is more suitable for the Croatian capital market than the variance-covariance VaR method. Research also shows that the variance-covariance VaR method attributes

Ines Megla, mag. oec., Orbico Beauty d.o.o., Koturaška 69, Zagreb

** Izv. prof. dr. sc. Nataša Kurnoga, Ekonomski fakultet Sveučilišta u Zagrebu, Trg J. F. Kennedyja 6, Zagreb.

*** Doc. dr. sc. Denis Dolinar, Ekonomski fakultet Sveučilišta u Zagrebu, Trg J. F. Kennedyja 6, Zagreb. 
more risk to the MRR and MV portfolios than the historical VaR method. On the other side, research shows that the variance-covariance VaR method attributes less risk to the CROBEX10 than the historical VaR method. In the most cases the MRR and MV portfolios have lower level of risk in relation to the CROBEX10 index. Finally, the MRR and MV portfolios that are tested out of a sample show greater level of risk in relation the MRR and MV portfolios that are tested in a sample.

KEY WORDS: Value-at-Risk, VaR, market risk, CROBEX10, efficient frontier.

\section{UVOD}

VaR metoda procjene tržišnog rizika korespondira s pretpostavkama biheviorističkih financija u pogledu da se rizik investitora isključivo sagledava kroz nepredvidljive događaje s negativnim učincima na njihovo bogatstvo. Takav, ljudima intuitivan, pristup riziku popularizirao je VaR metodu među investitorima, ali i među regulatorima tržišta kapitala.

Motivacija za ovo istraživanje proizašla je iz činjenice da je VaR metodu znatno teže primijeniti u okvirima slabije razvijenoga tržišta kapitala, kao što je i hrvatsko. Cilj rada je istražiti mogućnosti primjene različitih VaR metoda i stavit ih u kontekst sučeljavanja efikasnosti indeksa dioničkog tržišta prema odabranim portfolijima s efikasne granice. Hipoteza rada jest da indeks CROBEX10, mjereno VaR metodom, ne predstavlja optimalni investicijski portfolio, već da postoje portfoliji formirani od sastavnica indeksa CROBEX10, koji svojim rizično-profitnim obilježjima dominiraju u odnosu na sam indeks CROBEX10. Doprinos rada je analiza odnosa dviju VaR metoda s obzirom na promatrani tržišni indeks i odabrane portfolije s efikasne granice. Zaključci su izvedeni s obzirom na odnos tržišnog rizika između promatranoga tržišnog indeksa i odabranih portfolija s efikasne granice, kao i s obzirom na način na koji su preispitani odabrani portfoliji s efikasne granice.

Nedvojbeno je da već postoji značajan broj istraživanja koja su se bavila značajkama i primjenom VaR metoda na hrvatskome tržištu kapitala. Šverko (2001., 2002.) analizira mogućnost primjene VaR metode pri upravljanju rizicima financijskih institucija u Republici Hrvatskoj. Žiković (2005.) analizira mogućnost primjene različitih metoda izračuna VaR-a za hrvatsko dioničko tržište te zaključuje kako je za mjerenje tržišnog rizika najpogodnija povijesna VaR metoda. Arnerić, Jurun, i Pivac (2006.) nastoje modelirati volatilnost prinosa dionice Plive GARCH procesom u cilju boljeg prognoziranja rizične vrijednosti. Žiković, i Aktan (2009.) istražuju relativnu uspješnost različitih VaR modela na dnevnim prinosa hrvatskoga i turskoga dioničkog indeksa te zaključuju da u razdoblju krize većina VaR modela značajno podcjenjuje stvarnu razinu rizika. Čorkalo (2011.) te Bogdan, Baresa i Ivanović (2015.) uspoređuju rezultate različitih metoda izračuna VaR pokazatelja na primjeru jednostavnog portfolija sastavljenoga od pet odabranih dionica s hrvatskoga tržišta kapitala, pri čemu svaka dionica ima isto vrijednosno učešće. Miloš Sprčić i Radić (2011.) prikazuju komparativnu analizu VaR i CFaR metoda kao osnovnih tehnika kvantifikacije izloženosti rizika, a sve u cilju približavanja ovih metoda menadžerima u poduzećima i financijskim institucijama u Republici Hrvatskoj. Aljinović i Trgo (2017.) uspoređuju VaR i CVaR metodu na podacima s hrvatskoga dioničkog tržišta te konstatiraju da prednost treba dati CVaR metodi. Međutim, koliko je nama poznato, niti jedno istraživanje čiji je fokus bilo hrvatsko tržište kapitala se nije bavilo procjenom VaR pokazatelja u kontekstu suče- 
ljavanja efikasnosti konkretnog dioničkog indeksa s drugačijim, potencijalno efikasnijim, benchmark portfolijem.

Ovaj rad se sastoji od pet poglavlja. Nakon uvoda, u drugome poglavlju se tržišni rizik definira u kontekstu moderne teorije portfolija i povezuje s konceptom VaR metode. Treće poglavlje ukratko navodi prirodu podataka koji su neophodni za istraživanje i njihove izvore te daje okvir u kojemu se provodi istraživanje. Četvrto poglavlje predstavlja empirijski dio rada u kojemu se navode rizično-profitna obilježja indeksa CROBEX10 te praktično procjenjuju VaR pokazatelji. Peto poglavlje sadrži zaključke rada, ograničenja istraživanja te navodi smjernice za buduća istraživanja.

\section{TRŽIŠNI RIZIK I VAR METODA}

Tržišni rizik u svojoj srži proizlazi iz rizika promjene cijene, bez obzira radi li se o financijskim instrumentima, robama ili valutama. Razumijevanje koncepta rizika, upuštanje u investicije prihvatljivoga stupnja rizika te zaštita od neprihvatljivoga stupnja rizika danas predstavlja redovitu aktivnost racionalnih poslovnih subjekata, a naročito financijskih institucija. VaR metoda se pritom nametnula kao općeprihvaćeni koncept mjerenja tržišnog rizika.

\subsection{Tržišni rizik}

Iako u svakodnevnome životu većina ljudi rizik poistovjećuje s nepredvidivim događajem koji donosi negativne učinke na njihovo bogatstvo, u ekonomskome (posebice financijskome) smislu rizik ima širu definiciju. Ključnu ulogu u razvoju koncepta rizika u financijskome smislu imao je rodonačelnik moderne teorije portfolija nobelovac Harry M. Markowitz. U svojim radovima Markowitz (1952.; 1956.; 1959.) dotad korištenu analizu očekivanog prinosa investicije nadopunjuje s dvije nove dimenzije: (1) kvantifikacijom rizika pojedine investicije te (2) koreliranošću prinosa pojedine investicije s ostalim raspoloživim investicijama. Time je efekt diversifikacije rizika pri investiranju, koji je bio dobro poznat u praksi i stoljećima prije 1950-ih, u ranim Markowitzevim radovima dobio svoju formalnu ulogu i kvantitativan dokaz.

Konkretno, Markowitz (1952.) rizik investicije definira kao volatilnost očekivanog prinosa investicije (u oba smjera; na niže i više, tj. s pozitivnim i negativnim utjecajem na bogatstvo poslovnog subjekta) te ga stoga mjeri uobičajenom mjerom disperzije - varijancom. Dodatno, kako bi se ostvario pozitivni efekt diversifikacije Markowitz podrazumijeva da investitori moraju formirati svoje portfolije na način da težite maksimalno mogućem očekivanom prinosu portfolija u kombinaciji s minimalnom varijancom očekivanoga prinosa portfolija. Praktično, međuovisnost prinosa i rizika Markowitz (1952.) naziva pravilom „očekivani prinos - varijanca prinosa“1 te ju ocrtava kao efikasnu granicu koju čini skup dominantnih portfolija.

Engl. expected returns - variance returns rule ili skraćeno E-V rule. 
Kako bi se pojednostavnila praktična primjena Markowitzeve portfolio analize Sharpe (1963.) razvija koncept jedno-indeksnih modela. Time je omogućeno da se rizik pojedinog vrijednosnog papira analitički raščlani na tržišnu (sistematsku) i specifičnu komponentu. Kako se specifični rizik investicije može izbjeći formiranjem dobro diversificiranog portfolija, tako se tržišni (sistematski) rizik investicije nameće kao jedini rizik relevantan za investitora.

Daljnji razvoj moderne portfolio teorije išao je u smjeru razvoja teorija tržišta kapitala. Model procjenjivanja kapitalne imovine (eng. Capital Asset Pricing Model - CAPM) postao je okosnica za procjenjivanje tržišnog rizika (i očekivanog prinosa) vrijednosnih papira kod brojnih kasnijih teorijskih istraživanja, ali i modela u praktičnoj primjeni. U tome pogledu tržišni se portfolio, kao konstrukt CAPM-a, u praksi aproksimira prinosom indeksa dioničkoga tržišta, čime se dovodi u pitanje relevantnost tako utvrđenoga tržišnog rizika. Tako Haugen i Baker (1991.), Grinold (1992.) i kasnija istraživanja dovode u sumnju da dionički indeksi (ponderirani s obzirom na tržišnu kapitalizaciju svojih sastavnica) omogućavaju efikasno utemeljenje rizično-profitnog odnosa pojedine investicije. Kao rezultat toga, nova istraživanja pokrenuta su s ciljem pronalaženja efikasnih tržišnih indeksa.

\subsection{VaR metoda}

Rizična vrijednost ili VaR (Value-at-Risk) je mjera potencijalnih gubitaka portfolija i upravo je njezina najveća prednost prikaz poslovnih rezultata u jednom broju. Njezina primjena započela je u investicijskoj banci JP Morgan gdje se po završetku radnoga dana podnosilo dnevno izvješće o izloženosti portfolija banke riziku i potencijalnim gubicima u sljedeća 24 sata.

Za izračun VaR-a, potrebno je utvrditi temeljne tržišne faktore, primjerice tržišne stope i cijene koje utječu na vrijednost portfolija. Kako bi se procijenila rizična vrijednost, neophodno je odrediti vremensko razdoblje unutar kojega se želi procijeniti potencijalni gubitak te razinu pouzdanosti pri čemu su uobičajene razine pouzdanosti $95 \%$ ili $99 \%$. Treba naglasiti da se VaR računa za kraće vremensko razdoblje, primjerice za izračun potencijalnih gubitaka na dnevnoj bazi. Pri izboru razine pouzdanosti treba imati u vidu da što je manja razina pouzdanosti to je preciznija procjena i obrnuto. Prema tome, što je viša razina pouzdanosti, veći je iznos izračunatog maksimalnog gubitka što posljedično dovodi do većih troškova rezervacija odnosno potrebnih većih iznosa za pokrivanje potencijalnih gubitaka.

Tri su najčešće korištene metode izračuna VaR-a: povijesna metoda, metoda varijance-kovarijance i Monte Carlo metoda. Povijesna metoda, kao što joj i sam naziv govori, zasniva se na povijesnim podacima, dok metoda varijance-kovarijance i Monte Carlo metoda koriste povijesne podatke za procjenu statističkih parametara. $U$ radu su primijenjene povijesna metoda i metoda varijance-kovarijance, obje uz razinu pouzdanosti od $95 \%$ i $99 \%$, te su uspoređeni dobiveni rezultati.

Povijesna metoda izračuna VaR-a je statistički manje zahtjevna metoda te time i jednostavnija. To je neparametarska metoda i zasniva se na pretpostavci da će nadolazeća budućnost biti vrlo slična nedavnoj prošlosti. U praksi se uobičajeno uzima vremensko razdoblje od minimalno 100, zatim primjerice 500 radnih dana, do 2 ili 3 godine. Na osnovi povijesnih promjena, primjerice cijena i tečajeva, određuju se distribucije potencijalnih 
dobitaka i gubitaka portfolija te u konačnici VaR vrijednost, gdje je iznos VaR-a moguće odrediti iz iscrtanog histograma dobitaka i gubitaka portfolija.

Potrebno je formirati optimalni portfolio, identificirati tržišne faktore te formirati empirijsku distribuciju prinosa tako što se za promatrani portfolio izračunaju prinosi ostvareni u prošlosti za svako razdoblje. Primjerice, ako se promatrani portfolio sastoji od $n$ dionica u razdoblju $t$, za svaku tu dionicu $i$ postoje opažanja za svako razdoblje. U skladu s time, prinos portfolija $R_{t}^{p}$ u razdoblju $t$ izračunava se na sljedeći način:

$$
R_{t}^{p}=\sum_{i=1}^{n} w_{i} R_{i, t}
$$

gdje je $w_{i}$ udio imovine trenutno uložen u dionicu $i$, a $R_{i, t}$ prinos na dionicu $i$ u razdoblju $t$. Dobiveni povijesno simulirani prinosi se nanose na histogram, a potom se s histograma očitava iznos VaR-a uz odabranu razinu pouzdanosti.

Metoda varijance-kovarijance je, za razliku od povijesne metode, parametarska metoda. Pretpostavka primjene metode varijance-kovarijance je, za razliku od povijesne metode, da tržišni faktori imaju normalnu distribuciju.

U primjeni metode varijance-kovarijance, kao i kod povijesne metode, se promatraju povijesni podaci. Nakon utvrđivanja tržišnih faktora i izračuna vrijednosti portfolija, procjenjuje se matrica varijanci-kovarijanci prinosa po tržišnim faktorima, uz pretpostavku da su opisani multivarijatnom normalnom distribucijom. Nadalje, izračunava se koeficijent korelacije $(\rho)$ kao odnos kovarijance $(c o v)$ između tržišnih faktora i umnoška njihovih standardnih devijacija $(\sigma)$, te se izračunava standardna devijacija portfolija:

$$
\sigma_{p}=\sqrt{\sum_{i=j}^{n} w_{i}^{2} \sigma_{i}^{2}+2 \sum_{i=1}^{n} \sum_{j<i} \rho_{i, j} w_{i} w_{j} \sigma_{i} \sigma_{j}}
$$

gdje je $w_{i}^{2}$ udio pojedinog dijela dionice u ukupnoj dionici. Na osnovi dobivenoga procjenjuje se VaR pokazatelj kao umnožak standardne devijacije portfolija $\left(\sigma_{p}\right)$ i koeficijenta pouzdanosti standardizirane normalne distribucije $\left(z_{\alpha}\right)$. U konačnici vrijednost VaR-a određuje se na sljedeći način:

$$
\operatorname{VaR}=\sigma_{p} \cdot P \cdot z_{\alpha}
$$

gdje je $P$ inicijalna tržišna vrijednost portfolija.

\section{IZVOR PODATAKA I VREMENSKO RAZDOBLJE ISTRAŽIVANJA}

U radu su analizirani podaci o sastavnicama (dionicama) indeksa CROBEX10. Prvotno su analizirani dnevni prinosi sastavnica indeksa CROBEX10 od ožujka 2015. do veljače 2017. godine. Pritom se polazi od sastava druge revizije indeksa CROBEX10 za 2016. godinu (od rujna 2016. do ožujka 2017. godine, sastav indeksa dan je u tablici 1). Procjena VaR pokazatelja provedena je na navedenim dionicama kroz portfolio s maksimalnim odnosom 
prinosa i rizika te kroz originalna učešća dionica u indeksu CROBEX10. Pritom se procjena promatranog portfolija s maksimalnim odnosom prinosa i rizika zasniva na mjesečnim prinosima dionica, a procjena VaR pokazatelja na dnevnim prinosima dionica.

Nedostatak analize na dnevnoj bazi su nedostajući podaci. Naime, uobičajena je pojava da se pojedinom dionicom ne trguje jedan ili više dana. U tome slučaju podaci se mogu nadomjestiti ili prosječnom vrijednosti ili cijenom trgovanja prethodnoga dana što je primijenjeno i u ovome istraživanju. S druge strane, s promatranim dionicama u promatranome razdoblju na tjednoj razini uvijek se trgovalo. Stoga su, kako bi se izbjegao problem nedostajućih podataka, u sljedećoj fazi istraživanja analizirana tjedna opažanja cijena dionica.

Sastav druge revizije indeksa CROBEX10 za 2015. godinu (od rujna 2015. do ožujka 2016. godine, sastav indeksa dan je u tablici 1) referentan je za daljnju analizu. Analizirano je 26 tjednih opažanja. Procjena promatranih portfolija provedena je kao rezultat tjednih opažanja koja pripadaju promatranoj reviziji (optimizacija unutar promatranoga uzorka) i kao rezultat tjednih opažanja koja prethode promatranoj reviziji (optimizacija izvan promatranoga uzorka).

Za analizu unutar uzorka promatrani su podaci od rujna 2015. do ožujka 2016. godine, što je ujedno i referentna revizija indeksa (sastav druge revizije indeksa CROBEX10 za 2015. godinu). Za analizu izvan uzorka uzeti su podaci za 6 mjeseci ranije, ali za sastav indeksa razmatranoga uzorka odnosno za sastav druge revizije indeksa CROBEX10 za 2015. godinu. Dakle, analizirani su podaci za razdoblje od ožujka 2015. do rujna 2015. godine, a dobiveni rezultati testirani su na uzorku od rujna 2015. do ožujka 2016. godine.

\section{PRIMJENA VAR METODE U ANALIZI SASTAVNICA INDEKSA CROBEX10}

$\mathrm{U}$ fokusu racionalnih investitora je formiranje efikasnih portfolija koji dominiraju s obzirom na odnos prinosa i rizika, tj. formiranje portfolija koji će u perspektivi najbolje oslikavati tržišne rizike. Utoliko se u ovome radu procjena tržišnog rizika VaR metodom primarno promatra na sastavnicama indeksa CROBEX10 kroz portfolio s maksimalnim odnosom prinosa i rizika, a sekundarno i na portfoliju s minimalnom varijancom te samom indeksu CROBEX10 (u svome originalnom sastavu).

Varijabilnost metodologija istraživanja u ovome radu proizlazi iz sljedećih mogućnosti: (1) provođenje cjelokupnog istraživanja kroz duže (dvogodišnje) ili kraće (polugodišnje) vremensko razdoblje, (2) procjenu efikasnih portfolija na bazi tjednih ili mjesečnih prinosa dionica, (3) primjenu povijesne VaR metode ili VaR metode bazirane na varijancama i kovarijancama, (4) procjenu VaR pokazatelja na bazi dnevnih ili tjednih prinosa dionica, (5) pretpostavljenu razinu pouzdanosti procjene - 95\% ili 99\% te (6) procjenu VaR pokazatelja za optimizirani portfolio koji je određen na bazi opažanja koja pripadaju promatranome razdoblju ili na bazi opažanja koja prethode promatranome razdoblju.

\subsection{Rizično-profitna obilježja indeksa CROBEX10}

Slabije razvijena dionička tržišta, kao što je hrvatsko, također nose određena individualna ograničenja i specifičnosti. Tu do izražaja naročito dolazi činjenica da je hrvatsko 
dioničko tržište plitko, u smislu skromnoga stupnja likvidnosti, usko, u smislu ograničenoga broja dionica zanimljivih za analizu, i mlado, u smislu svoje kratke povijesti.

Zagrebačka burza predstavlja središnje mjesto hrvatskoga tržišta kapitala. Dinamiku cjelokupnoga hrvatskog dioničkog tržišta najbolje prikazuju indeksi CROBEX i CROBEX10. U ovome radu prednost je dana indeksu CROBEX10, budući da zbog manjeg broja dionica u indeksu bolje predstavlja značajke likvidnijeg dijela dioničkoga tržišta, tj. dionice u sastavu indeksa CROBEX10 najbolje zadovoljavaju kriterije free float tržišne kapitalizacije i likvidnosti te pripadaju različitim industrijskim sektorima.

Tablica 1. Karakteristike i sastav indeksa CROBEX10 u razdoblju od ožujka 2015. do ožujka 2017.

\begin{tabular}{|c|c|c|c|c|c|c|c|}
\hline \multicolumn{8}{|c|}{ Karakteristike indeksa CROBEX10: } \\
\hline \multicolumn{2}{|c|}{ Vrsta } & \multicolumn{6}{|c|}{ Cjenovni indeks, dividende se ne uključuju u izračun. } \\
\hline \multicolumn{2}{|l|}{ Sastav } & \multicolumn{6}{|c|}{$\begin{array}{l}10 \text { dionica iz indeksa CROBEX s najvećom free float tržišnom } \\
\text { kapitalizacijom i prometom. }\end{array}$} \\
\hline \multicolumn{2}{|c|}{ Broj sastavnica } & \multicolumn{6}{|c|}{10} \\
\hline \multicolumn{2}{|c|}{ Težine } & \multicolumn{6}{|c|}{ Free float tržišna kapitalizacija. } \\
\hline \multicolumn{2}{|c|}{$\begin{array}{l}\text { Maksimalna } \\
\text { težina pojedine } \\
\text { sastavnice }\end{array}$} & \multicolumn{6}{|c|}{$20 \%$} \\
\hline \multicolumn{2}{|c|}{ Revizija } & \multicolumn{6}{|c|}{ Polugodišnje, četvrti petak u mjesecu ožujku i rujnu. } \\
\hline \multicolumn{2}{|c|}{ Bazni datum } & \multicolumn{6}{|c|}{ 31. 7. 2009.} \\
\hline \multicolumn{2}{|l|}{$\begin{array}{l}\text { Bazna } \\
\text { vrijednost }\end{array}$} & \multicolumn{6}{|l|}{1000} \\
\hline \multicolumn{8}{|c|}{ Sastav po revizijama indeksa CROBEX10: } \\
\hline Ticker & \multicolumn{2}{|c|}{ Naziv poduzeća } & 2015-R1 & 2015-R2 & 2016-R1 & 2016-R2 & Ukupno \\
\hline ADPL-R-A & \multicolumn{2}{|c|}{ AD Plastik d.d. } & 1 & \begin{tabular}{l|l}
1 \\
\end{tabular} & & & 2 \\
\hline ADRS-P-A & \multicolumn{2}{|c|}{ Adris grupa d.d. } & 1 & 1 & 1 & 1 & 4 \\
\hline ATGR-R-A & \multicolumn{2}{|c|}{ Atlantic Grupa d.d. } & 1 & 1 & 1 & 1 & 4 \\
\hline ERNT-R-A & \multicolumn{2}{|c|}{$\begin{array}{l}\text { Ericsson Nikola } \\
\text { Tesla d.d. }\end{array}$} & 1 & 1 & 1 & 1 & 4 \\
\hline HIMR-R-A & \multicolumn{2}{|c|}{ Imperial d.d. } & & & & 1 & 1 \\
\hline HT-R-A & \multicolumn{2}{|c|}{ HT d.d. } & 1 & 1 & 1 & 1 & 4 \\
\hline INA-R-A & \multicolumn{2}{|c|}{ Ina d.d. } & 1 & 1 & 1 & & 3 \\
\hline KOEI-R-A & \multicolumn{2}{|c|}{$\begin{array}{l}\text { Končar - } \\
\text { elektroindustrija d.d. }\end{array}$} & 1 & 1 & 1 & 1 & 4 \\
\hline KRAS-R-A & \multicolumn{2}{|c|}{ Kraš d.d. } & & 1 & 1 & 1 & 3 \\
\hline LEDO-R-A & \multicolumn{2}{|c|}{ Ledo d.d. } & 1 & & 1 & 1 & 3 \\
\hline PODR-R-A & \multicolumn{2}{|c|}{ Podravka d.d. } & 1 & 1 & 1 & 1 & 4 \\
\hline RIVP-R-A & \multicolumn{2}{|c|}{ Valamar Riviera d.d. } & 1 & 1 & 1 & 1 & 4 \\
\hline Ukupno & & & 10 & 10 & 10 & 10 & \\
\hline
\end{tabular}

Izvor: izrada autora prama podacima Zagrebačke burze. 
U promatranome razdoblju (od ožujka 2015. do ožujka 2017.) hrvatsko dioničko tržište je doživjelo blagi oporavak uz zadržavanje skromne razine trgovanja. Detaljniji prikaz dinamike tržišta i rizično-profitnih karakteristika indeksa CROBEX10 vidljiv je na grafikonu 1. Dosadašnja istraživanja povezana s indeksom CROBEX (Dolinar, Zoričić \& Kožul, 2017.) pokazala su da se isti ne nalazi na efikasnoj granici svojih sastavnica što ukazuje na njegovu neefikasnost u smislu primjene kao efikasnog benchmarka domaćeg tržišta kapitala. Slična situacija je i s indeksom CROBEX10 u promatranome razdoblju. Isto je ilustrativno prikazano na grafikonu 2, na primjeru druge revizije indeksa u 2015. godini, na način da je točka rizično-profitnog obilježja indeksa CROBEX10 značajno udaljena od efikasne granice svojih sastavnica (time i od dva specifična portfolija s efikasne granice: portfolija s maksimalnim odnosom prinosa i rizika te portfolija s minimalnom varijancom).

Grafikon 1. Kretanje indeksa i dnevnog prometa te rizično-profitna obilježja indeksa CROBEX10
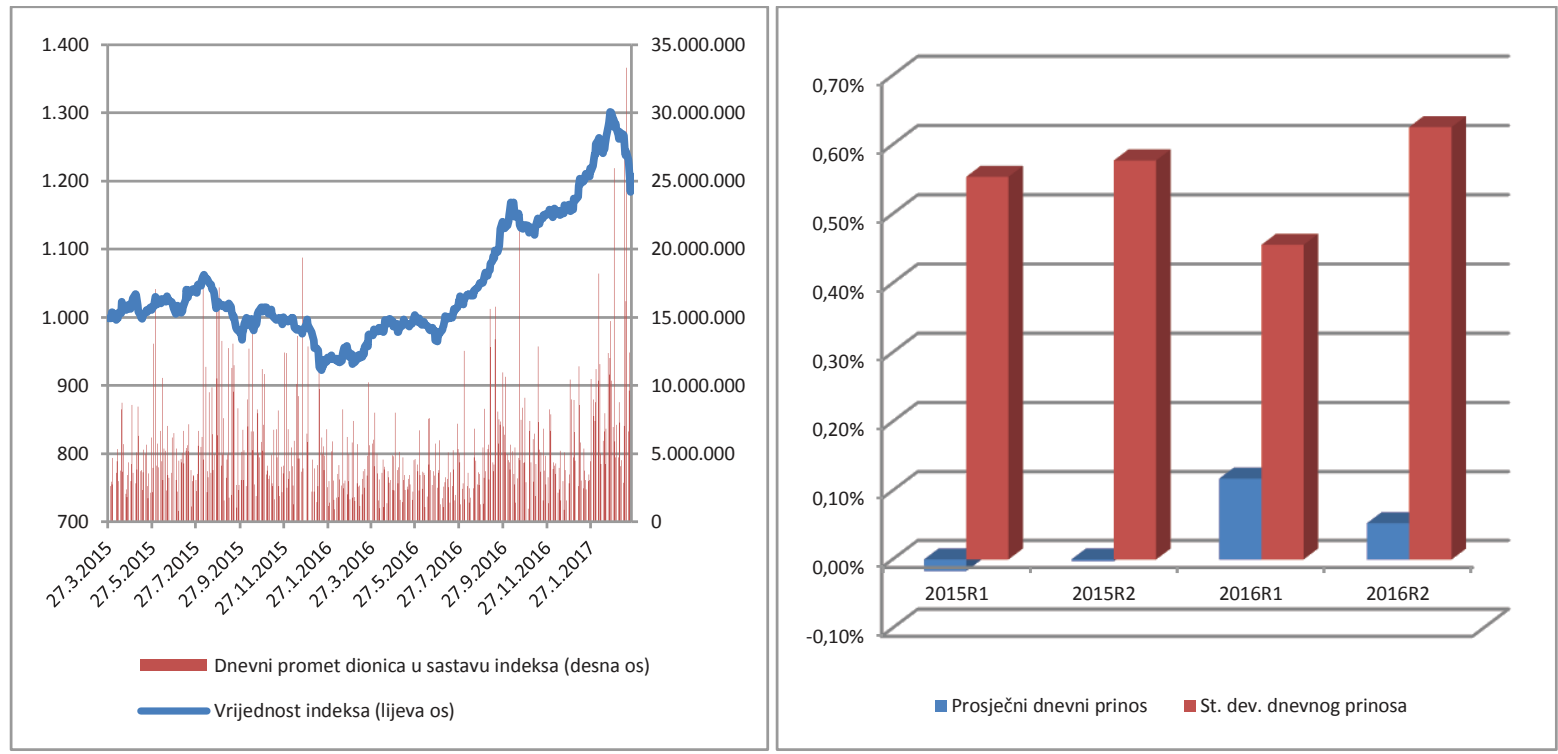

Izvor: izrada autora prema podacima Zagrebačke burze.

Grafikon 2. Položaj indeksa CROBEX10 i efikasne granice njegovih sastavnica (druga revizija 2015. godine)

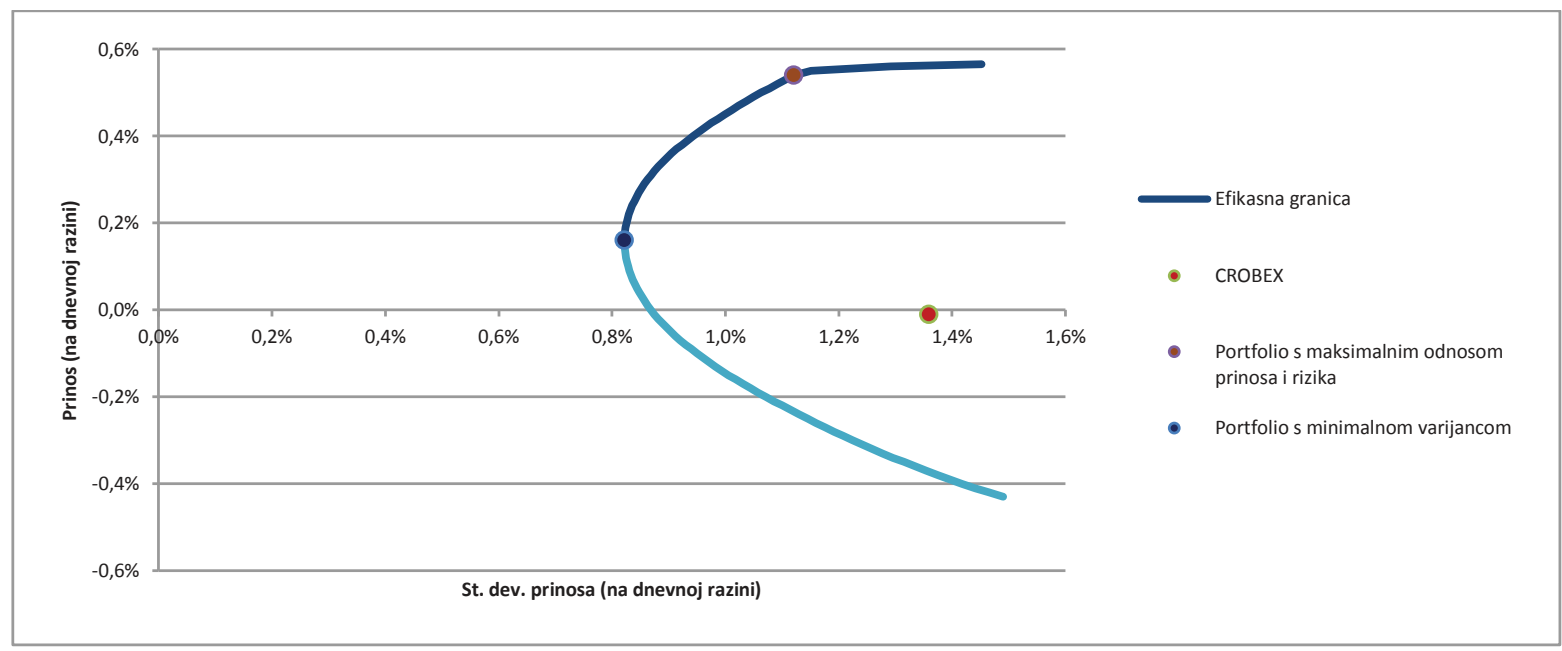

Izvor: izrada autora. 


\subsection{Primjena VaR metode na bazi dnevnih opažanja unutar ukupnog promatranog razdoblja}

u ovome dijelu istraživanja procjena VaR pokazatelja temeljena je na sastavu druge revizije indeksa CROBEX10 za 2016. godinu (rujan 2016. - ožujak 2017; za sastav indeksa vidi tablicu 1). Preciznije, procjena tržišnog rizika VaR metodom promatra se na sastavnicama indeksa CROBEX10 kroz portfolio s maksimalnim odnosom prinosa i rizika (MPR) te kroz indeks CROBEX10 (originalna učešća dionica). Procjena promatranoga (MPR) portfolija $^{2}$ i procjene VaR pokazatelja provedene su na podacima za ukupno promatrano razdoblje - od ožujka 2015. do veljače 2017. Pritom je procjena promatranoga portfolija temeljena na mjesečnim prinosima dionica, dok je procjena VaR pokazatelja temeljena na dnevnim prinosima dionica. Pri procjeni VaR pokazatelja primijenjene su povijesna VaR metoda i VaR metoda varijanci-kovarijanci, obje uz razinu pouzdanosti od $95 \%$ i $99 \%$.

Povijesna VaR metoda promatra vremenski niz prinosa optimalnog MPR portfolija kao i vremenski niz prinosa indeksa CROBEX10. Utvrđivanjem 1. i 5. percentila navedenih vremenskih nizova određeni su VaR pokazatelji uz 99\% i 95\%-tnu razinu pouzdanosti. Iste vrijednosti je moguće očitati i pomoću histograma (vidi grafikon 3).

Grafikon 3. Histogram distribucije dnevnih prinosa MPR portfolija i procjena VaR pokazatelja uz razinu pouzdanosti $95 \%$

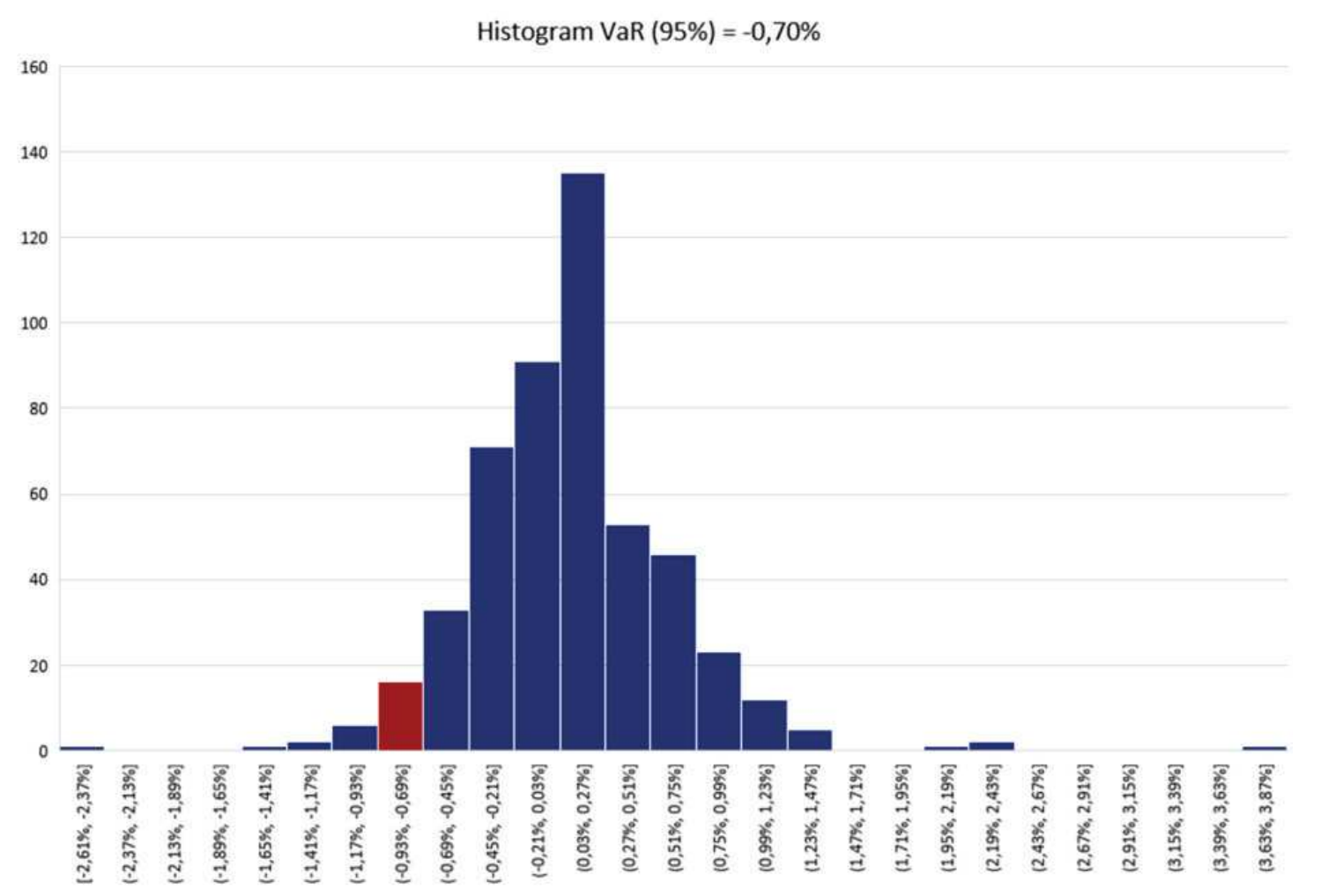

Izvor: izrada autora.

$2 \quad$ Određivanje promatranih portfolija rezultat je provedene nelinearne optimizacije u programu Excel (MS Office). Pritom je pretpostavljen uvjet nenegativnosti vrijednosnih učešća za promatrane dionice iz sastava indeksa CROBEX10. 
Procjena VaR pokazatelja metodom varijance-kovarijance, pod pretpostavkom normalne distribucije, dobivena je kao umnožak standardne devijacije vremenskog niza prinosa promatranih portfolija (MPR i CROBEX10) i standardizirane vrijednosti normalne distribucije (-1,645 za 95\%-tnu, odnosno -2,326 za 99\%-tnu razinu pouzdanosti). Konačni rezultati procjene VaR pokazatelja nalaze se u tablici 2.

Tablica 2. Procjene VaR pokazatelja na bazi dnevnih opažanja unutar ukupnog promatranog razdoblja

\begin{tabular}{|l|c|c|c|}
\hline \multicolumn{1}{|c|}{ Portfolio } & VaR metoda & $\begin{array}{c}\text { Razina pouzdanosti } \\
\mathbf{9 5 \%}\end{array}$ & $\begin{array}{c}\text { Razina pouzdanosti } \\
\mathbf{9 9 \%}\end{array}$ \\
\hline MPR portfolio & VaR, povijesna & $-0,709 \%$ & $-0,983 \%$ \\
\hline CROBEX10 & VaR, povijesna & $-0,804 \%$ & $-1,248 \%$ \\
\hline MPR portfolio & VaR, var.-kovar. & $-0,880 \%$ & $-1,244 \%$ \\
\hline CROBEX10 & VaR, var.-kovar. & $-0,872 \%$ & $-1,233 \%$ \\
\hline
\end{tabular}

Izvor: izračun autora.

Iz rezultata je vidljivo da se procijenjeni maksimalni dnevni gubici u promatranome razdoblju uz razinu pouzdanosti od $95 \%$ kreću u rasponu od $0,71 \%$ do $0,88 \%$, dok se uz razinu pouzdanosti od $99 \%$ kreću u rasponu od $0,98 \%$ do 1,25\%. Također, u promatranome razdoblju povijesna VaR metoda i VaR metoda varijanci-kovarijanci daju suprotstavljene zaključke u smislu da prva implicira veći tržišni rizik indeksa CROBEX10, dok druga implicira veći tržišni rizik portfolija s maksimalnim odnosom prinosa i rizika.

\subsection{Primjena VaR metode temeljem tjednih opažanja na odabranoj reviziji indeksa CROBEX10}

U ovomE potpoglavlju istraživanje se isključivo usredotočuje na procjenu VaR pokazatelja za razdoblje važenja sastava druge revizije indeksa CROBEX10 za 2015. godinu (rujan 2015. - ožujak 2016; za sastav indeksa vidi tablicu 1). Preciznije, procjena tržišnog rizika VaR metodom promatra se na sastavnicama indeksa CROBEX10 kroz portfolio s maksimalnim odnosom prinosa i rizika (MPR), kroz portfolio s minimalnom varijancom (MV) te kroz indeks CROBEX10 (originalna učešća dionica). Pritom je procjena promatranih (MPR i MV) portfolija izvedena kao rezultat tjednih opažanja koja pripadaju promatranoj reviziji (optimizacija unutar promatranoga uzorka), ali i kao rezultat tjednih opažanja koja prethode promatranoj reviziji (prethodno optimiziranje, tj. optimizacija izvan promatranoga uzorka). Za razliku od prethodnoga potpoglavlja, procjena VaR pokazatelja ovdje je temeljena na tjednim prinosima dionica. Slično kao i u prethodnome potpoglavlju pri procjeni VaR pokazatelja primijenjene su povijesna VaR metoda i VaR metoda temeljena na varijancama i kovarijancama, obje uz razinu pouzdanosti od 95\% i 99\%.

Tehnika izračuna VaR pokazatelja istovjetna je onoj iz prethodnoga potpoglavlja. Povijesna VaR metoda usmjerena je na utvrđivanje 1. i 5. percentila vremenskih nizova prinosa promatranih portfolija, dok je VaR metoda varijanci-kovarijanci određena umnoškom standardnih devijacija prinosa promatranih portfolija sa standardiziranim vrijednostima normalne distribucije. Konačni rezultati procjene VaR pokazatelja nalaze se u tablici 3. 
Tablica 3. Procjene VaR pokazatelja za promatranu reviziju indeksa CROBEX10 temeljem tjednih opažanja

\begin{tabular}{|c|c|c|c|c|c|}
\hline & \multicolumn{4}{|c|}{$\begin{array}{c}\text { Procjena promatranih portfolija (MPR i MV) kao } \\
\text { rezultat optimizacije: }\end{array}$} \\
\hline & & \multicolumn{2}{|c|}{ unutar uzorka } & \multicolumn{2}{|c|}{ izvan uzorka } \\
\hline Portfolio & VaR metoda & $\begin{array}{c}\text { Razina } \\
\text { pouzdanosti } \\
95 \%\end{array}$ & \begin{tabular}{|c|} 
Razina \\
pouzdanosti \\
$99 \%$
\end{tabular} & $\begin{array}{c}\text { Razina } \\
\text { pouzdanosti } \\
95 \%\end{array}$ & $\begin{array}{c}\text { Razina } \\
\text { pouzdanosti } \\
99 \%\end{array}$ \\
\hline MPR portfolio & VaR, povijesna & $-1,150 \%$ & $-1,705 \%$ & $-1,224 \%$ & $-2,304 \%$ \\
\hline MV portfolio & VaR, povijesna & $-1,298 \%$ & $-1,521 \%$ & $-2,031 \%$ & $-2,962 \%$ \\
\hline CROBEX10 & VaR, povijesna & $-2,616 \%$ & $-3,617 \%$ & - & - \\
\hline MPR portfolio & VaR, var.-kovar. & $-1,829 \%$ & $-2,587 \%$ & $-1,844 \%$ & $-2,608 \%$ \\
\hline MV portfolio & VaR, var.-kovar. & $-1,326 \%$ & $-1,875 \%$ & $-2,140 \%$ & $-3,026 \%$ \\
\hline CROBEX10 & VaR, var.-kovar. & $-2,303 \%$ & $-3,257 \%$ & - & - \\
\hline
\end{tabular}

Izvor: izračun autora.

Iz rezultata je vidljivo da se procijenjeni maksimalni tjedni gubici u vremenskome razdoblju promatrane revizije uz razinu pouzdanosti od $95 \%$ kreću u rasponu od 1,15\% do 2,62\%, dok se uz razinu pouzdanosti od 99\% kreću u rasponu od 1,52\% do 3,62\%. Za razliku od prethodnoga potpoglavlja, u promatranoj reviziji povijesna VaR metoda i VaR metoda varijanci-kovarijanci daju istovjetne zaključke u smislu da je tržišni rizik indeksa CROBEX10 veći od oba promatrana portfolija (MPR i MV).

\section{ZAKLJUČAK}

Činjenica je da je danas poznavanje i upravljanje tržišnim rizicima ključna odrednica racionalnog investitora, bilo da se radi o pojedincu, proizvodnom poduzeću, financijskoj instituciji ili državi. U tom pogledu VaR metode predstavljaju intuitivan alat kojega u praksi prihvaća veliki broj tržišnih sudionika. Iako postoji značajan broj istraživanja na temu primjene VaR metoda na hrvatskome tržištu kapitala, niti jedno se prema našim saznanjima nije odnosilo na procjenu VaR pokazatelja u kontekstu efikasnosti indeksa dioničkog tržišta i odabranih portfolija s efikasne granice njegovih sastavnica.

Temeljem provedenoga istraživanja za promatrano razdoblje i za promatrani segment hrvatskoga tržišta kapitala moguće je izvesti sljedeće zaključke. (1) Povijesna VaR metoda može se smatrati pogodnijom za hrvatsko tržište kapitala u odnosu na VaR metodu varijanci-kovarijanci. Na ovaj zaključak ukazuju značajne razlike procijenjenih VaR pokazatelja između ovih dviju metoda bez obzira na razinu pouzdanosti, dužinu promatranoga razdoblja, tip portfolija ili podatke temeljem kojih su formirani promatrani portfoliji. Naime, kod povijesne VaR metode procijenjeni prinosi bliži su ostvarenima. Ovaj zaključak je u skladu s istovjetnim zaključcima prijašnjih istraživanja (npr. Žiković, 2005.). Rezultat je to promjenjivosti stupnja volatilnosti i koreliranosti prinosa dionica na hrvatskome tržištu, zajedno s odstupanjem oblika distribucije prinosa u odnosu na normalnu distribuciju. (2) Kod portfolija s maksimalnim odnosom prinosa i rizika (MPR) i portfolija s minimalnom 
varijancom (portfolio MV) VaR metoda varijanci-kovarijanci iskazivala je veći stupanj rizika (veće razine potencijalnih gubitaka) u odnosu na povijesnu VaR metodu. S druge strane, kod indeksa CROBEX10, za promatranu reviziju i tjedna opažanja, VaR metoda varijanci-kovarijanci iskazivala je manji stupanj rizika u odnosu na povijesnu VaR metodu. Razlozi za ovakav nalaz mogu se tražiti u činjenici da promatrani portfoliji (MPR i MV) imaju manji broj sastavnica u odnosu na indeks CROBEX10 te nemaju ograničenje maksimalnog učešća pojedine dionice u portfoliju. (3) Promatrani portfoliji (MPR i MV) u većini slučajeva iskazuju manji stupanj rizika (manju vrijednost potencijalnoga gubitka) u odnosu na indeks CROBEX10 bez obzira na razinu pouzdanosti ili podatke temeljem kojih su formirani promatrani portfoliji. Razloge za ovo treba tražiti u činjenici da su navedeni portfoliji rezultat optimizacije i kao takvi svojim rizično-profitnim značajkama dominiraju nad indeksom CROBEX10. (4) Promatrani portfoliji (MPR i MV) koji su procijenjeni kao rezultat optimizacije opažanja koja prethode promatranoj reviziji (izvan uzorka) iskazuju veći stupanj tržišnog rizika u odnosu na promatrane portfolije (MPR i MV) koji su procijenjeni kao rezultat optimizacije opažanja koja pripadaju promatranoj reviziji (unutar uzorka), bez obzira na razinu pouzdanosti i metodu procjene VaR pokazatelja. Navedena činjenica ukazuje na to da je nužno dodatna istraživanja usmjeriti pronalaženju tržišnih indeksa koji bi kontinuirano kroz vrijeme dominirali svojom efikasnošću. U tom pogledu portfolio s maksimalnim odnosom prinosa i rizika (MPR) i portfolio s minimalnom varijancom (MV) predstavljaju tek prvi korak u smjeru udaljavanja od postojećih indeksa dioničkih tržišta.

Ovo istraživanje ima svojih ograničenja. Većim dijelom ta ograničenja su rezultat slabo razvijenoga domaćeg tržišta kapitala. U tome smislu slaba likvidnost i transparentnost tržišta smanjuje mogućnost primjene VaR metode na portfolijima i indeksima s većim brojem sastavnica. Česte izmjene sastava promatranoga indeksa, zajedno s nepostojanjem odgovarajuće dugih vremenskih nizova, predstavljaju značajni istraživački limit te ukazuju na potrebu primjene kompleksnijih metoda analize i tehnika procjene potrebnih ulizanih parametara.

Ovaj rad predstavlja tek početak dubljeg istraživanja u ovome području. Postojeće istraživanje nužno je proširiti u više smjerova, na primjer: (1) kroz dužinu vremenskog obuhvata, (2) kroz razvoj novih metoda za pronalaženje efikasnijih benchmark portfolija, (3) kroz primjenu VaR metode temeljene na Monte Carlo simulacijama, (4) kroz fokusiranje na procjene VaR pokazatelja efikasnih portfolija isključivo temeljem opažanja koja prethode analiziranome razdoblju (tj. testiranju procjena izvan uzorka) te (5) kroz proširenje geografskog obuhvata na način da se poveća baza likvidnih vrijednosnih papira.

\section{LITERATURA:}

1. Aljinović, Z. \& Trgo, A. (2017). Does CVaR overcome VaR on the Croatian Stock Market. The 14th International Symposium on Operational Research in Slovenia. 391-396.

2. Arnerić, J., Jurun, E. \& Pivac, S. (2006). Parametric forecasting of value at risk using heavy tailed distribution. Proceedings of the 11th International Conference on Operational Research: KOI 2006, 65-76. 
3. Bogdan, S., Baresa, S. \& Ivanović, Z. (2015). Estimating risk on the capital market with VaR method. UTMS Journal of Economics, 6(1), 165-175.

4. Čorkalo, Š. (2011). Comparison of Value at Risk Approaches on a Stock Portfolio. Croatian Operational Research Review, 2(1), 81-90.

5. Dolinar, D., Zoričić, D., \& Kožul, A. (2017). Towards the Estimation of an Efficient Benchmark Portfolio: The Case of Croatian Emerging Market. Zagreb International Review of Economics and Business, 20(s1), 13-23.

6. Grinold, R. C. (1992). Are benchmark portfolios efficient?. The Journal of Portfolio Management, 19(1), 34-40.

7. Haugen, R. A., \& Baker, N. L. (1991). The efficient market inefficiency of capitalization-weighted stock portfolios. The Journal of Portfolio Management, 17(3), 35-40.

8. Markowitz, H. (1952). Portfolio selection. The journal of finance, 7(1), 77-91.

9. Markowitz, H. (1956). The optimization of a quadratic function subject to linear constraints. Naval Research Logistics (NRL), 3(1-2), 111-133.

10. Markowitz, H. (1959). Portfolio Selection, Efficent Diversification of Investments. J. Wiley.

11. Miloš Sprčić, D. \& Radić, D. (2011). Kvantifikacija izloženosti rizicima-usporedba i ocjena metoda VaR i CFaR. Zbornik Ekonomskog fakulteta u Zagrebu, 9(1), 55-70.

12. Sharpe, W. F. (1963). A simplified model for portfolio analysis. Management science, 9(2), 277-293.

13. Šverko, I., (2001). Moguća primjena povijesne metode rizične vrijednosti pri upravljanju rizicima financijskih institucija u Republici Hrvatskoj. Financijska teorija $i$ praksa, 25(4), 605-618.

14. Šverko, I., (2002). Rizična vrijednost (value at risk) kao metoda upravljanja rizicima u financijskim institucijama. Ekonomski pregled, 53(7-8), 640-657.

15. Žiković, S., (2005). Formiranje optimalnog portfelja hrvatskih dionica i mjerenje trŽišnog rizika primjenom VaR metode. Magistarski rad, Sveučilište u Ljubljani, Ekonomski fakultet, Ljubljana.

16. Žiković, S. \& Aktan, B. (2009). Global financial crisis and VaR performance in emerging markets: A case of EU candidate states-Turkey and Croatia. Proceedings of Rijeka Faculty of Economics, Journal of Economics and Business, 27(1), 149-170. 